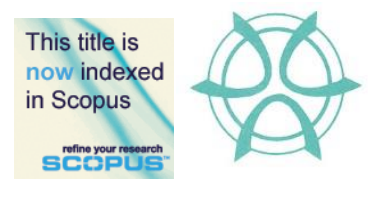

PLANNING MALAYSIA:

Journal of the Malaysian Institute of Planners

SPECIAL ISSUE V (2016), Page 65 - 76

\title{
SUSTAINABLE HOUSING AFFORDABILITY IN SABAH
}

\author{
Rosli Said $^{1}$, Rohayu Ab Majid ${ }^{2}$, Anuar Alias ${ }^{3}$, Yasmin Mohd Adnan ${ }^{4} \&$ \\ Muhammad Najib Razali ${ }^{5}$ \\ ${ }^{1,3,4}$ Centre for Sustainable Urban Planning \& Real Estate \\ Faculty of Built Environment \\ UNIVERSITY OF MALAYA, MALAYSIA \\ ${ }^{2}$ Department of Estate Management \\ Faculty of Architecture Planning \& Surveying \\ UNIVERSITI TEKNOLOGI MARA, MALAYSIA \\ ${ }^{5}$ Department of Real Estate \\ Faculty of Geoinformation \& Real Estate \\ UNIVERSITI TEKNOLOGI MALAYSIA
}

\begin{abstract}
Sabah is one of the states in Malaysia has shown remarkable growth in housing industry where its housing sector has thrived owing to growing market and active supply and demand dynamics. However, the rapid increase in housing price has created greater concern among the researchers about the sustainability of the housing sector in this country. The aspect of sustainability has seem been neglected by the industry players. Consequently, it will give impact to the environment which contrasts with the aim of the built environment to create sustainable development. This is because affordable housing is always being associated with cheap and low-quality houses. This research is aim to assess the best area in the state of Sabah to build sustainable affordable housing scheme. The results indicate that area with high utility degree is the best area that conforms to the sustainable housing affordability factors. Likewise, an area with a lower ranking in utility degree can be described as a worst-performing area. The originality of this research has contributed to a real picture of sustainable housing affordability in Malaysia, particularly the state of Sabah.
\end{abstract}

Keyword: COPRAS, MCDM, Sustainable, Housing, Affordability 
Rosli Said, Rohayu Ab Majid, Anuar Alias, Yasmin Mohd Adnan \& Muhammad Najib Razali

Sustainable Housing Affordability in Sabah

\section{INTRODUCTION}

The National Malaysian Housing Policy requires that the government aspires to accommodate the population with quality and affordable housing. In dealing with housing development, Malaysia has come out with extensive laws covering sustainable development through physical, economic, social and environmental aspects. Environmental performance, water treatment or energy efficiency forms the concept of ecologically sustainable development (Pullen et al., 2010). Although this concept of sustainable development is relatively acceptable in Malaysia, it is still debatable and open to more critical solutions. Abidin (2010) believes that competition between property developers has encouraged them to embrace the concept of sustainability as their main marketing campaign in any of their housing developments.

Although sustainable housing affordability has generated much interest among researchers, none of the local studies has focused on this area. Therefore, this study tries to address that gap with the aim to establish the sustainability area of housing that is considered affordable, at least in the Malaysian context. For this reason, the Multi-Criteria Decision Making (MCDM) framework is utilised through the Multi-Attribute Complex Proportional Assessment (COPRAS) method. In order to gain more insight into the study, this paper is organised as follows. First, relevant literature encompasses the concept of sustainable housing affordability is discussed. Then, follows the discussion on the criteria of sustainable housing affordability and the tools used in assessing sustainability. Then, analysis and conclusion of the paper are presented and discussed.

\section{LITERATURE REVIEW}

\section{Defining Sustainable Housing Affordability}

Brundtland (1996) defined sustainability as "development that meets the needs of the present without compromising the ability of future generations to meet their own needs". However, debates among researchers within the scope of this definition retarded the progress of making the concept of sustainability operational. In the most recent definition, sustainability refers to the observation of balancing between the three concepts namely economic development, social equity and environmental protection (Drexhage \& Murphy, 2010). In a broader aspect, sustainability would also include social attributes, human values and ecological (Kates, Parris \& Leiserowitz, 2005).

Medineckiene et al. (2010) highlighted the need to consider the current situation of economic, social and built environment in making decision as more and more citizens have come to live in inadequate shelters. Maliene and Malys (2009) further interpret sustainable housing as those that are well available, high quality, economical, ecological, aesthetical design, comfortable, and cosy. Sustainable housing should also consider not only the short and long-term costs 
of running a home but also cost-efficiency with good energy, waste, and water management.

The concept of 'sustainable housing affordability' was introduced by Mulliner and Maliene (2011) in which they established an initial system of criteria for sustainable housing affordability, among others, house price, quality and proximity to commercial area, hospital and entertainment. Mulliner and Maliene (2011) further argue that other criteria such as location, social, environment and economic sustainability of the housing shall not be isolated from housing affordability. Mulliner, Smallbone and Maliene (2013) argue that the abandonment of and low demand for housing units is due to their location which is not well connected to jobs, high-quality services and infrastructure. Therefore, sustainability should deal with the major backbone of housing design and a fundamental dimension of housing quality (Morgan \& Talbot, 2001). Physical attributes supported by community involvement and the challenge of getting the right 'mix' are the pre-requisite for sustainable housing affordability (Turcu, 2012).

\section{Criteria for Sustainable Housing Affordability}

A framework to determine the criteria of sustainability has been developed by Pullen et al. (2010). The sustainability criteria set by him consist of the core elements such as efficiency, construction, procurement, affordability, desirability, dwelling sizes, appropriate density, adaptability and social acceptability. Mcalpine \& Birnie (2007) introduced strategic indicators to monitor the quantifiable sustainability themes namely, among others, the quality of housing, environment quality, land use, household and commercial waste and local transportation. Table 1 shows the combination of criteria for sustainable housing affordability obtained from previous studies. However, the concept of sustainable housing affordability to be established in Malaysia is not ideal to be implemented in other countries due to different culture, preferences and attitude. This paper will suite suitable elements with local needs from the sustainable and affordable housing theoretical concept.

Table 1: Criteria for sustainable housing affordability

\begin{tabular}{lll}
\hline \multicolumn{2}{c}{$\begin{array}{c}\text { Sustainable Housing Affordability } \\
\text { Factors }\end{array}$} & \multicolumn{1}{c}{ Sources } \\
\hline 1 & House Price & (Burke et al., 2007; Mulliner \& Maliene, 2011) \\
& & $\begin{array}{l}\text { (Department of the Environment Heritage and Local } \\
\text { Government, 2007; Mulliner \& Maliene, 2011; The } \\
\text { Ministry of Urban Wellbeing Housing and Local } \\
\text { Government, 2013) }\end{array}$ \\
& House Quality & (Hurtubia et al., 2010) \\
3 & House Type & (Fierro et al., 2009) \\
5 & House Finishes & (Fierro et al., 2009)
\end{tabular}


Rosli Said, Rohayu Ab Majid, Anuar Alias, Yasmin Mohd Adnan \& Muhammad Najib Razali

Sustainable Housing Affordability in Sabah

\begin{tabular}{|c|c|c|}
\hline 6 & Interior Features & (Hurtubia et al., 2010) \\
\hline 7 & $\begin{array}{l}\text { Position of the House in } \\
\text { Layout Plan }\end{array}$ & (Hurtubia et al., 2010) \\
\hline 8 & Size of Built-up Area & (Fierro et al., 2009) \\
\hline 9 & Size of Land Area & (Fierro et al., 2009) \\
\hline 10 & Built-up Area & (Fierro et al., 2009) \\
\hline 11 & Age of the House & (Fierro et al., 2009) \\
\hline 12 & Topography & (Fierro et al., 2009) \\
\hline 13 & Property Interest & $(\mathrm{Lu}, 2002)$ \\
\hline 14 & Near to Commercial Area & (Mulliner \& Maliene, 2011; Samuels, 2004) \\
\hline 15 & Near to Hospitals & (Mulliner \& Maliene, 2011; Zhu et al.,2006) \\
\hline 16 & Near to Post Office & Own research \\
\hline 17 & Near to Entertainment & (Isalou et al., 2014; Mulliner \& Maliene, 2011) \\
\hline 18 & Near to Transportation & $\begin{array}{l}\text { (Australian Conservation Foundation, 2008; Mulliner } \\
\text { \& Maliene, 2011) }\end{array}$ \\
\hline 19 & Near to Place of Worship & Own research \\
\hline 20 & Near to Education & $\begin{array}{l}\text { (Clark et al., 2006; Mulliner \& Maliene, 2011; } \\
\text { Samuels, 2004) }\end{array}$ \\
\hline 21 & Near to Workplace & (King, 2008; Mulliner \& Maliene, 2011) \\
\hline 22 & Environment Quality & (CABE SPACE, 2005; Zhu et al., 2006) \\
\hline 23 & Security & (Hipp, 2010; Samuels, 2004) \\
\hline 24 & Traffic Congestion & (Brownstone \& Golob, 2009; Shen et al., 2011) \\
\hline 25 & Density & (Brownstone \& Golob, 2009; Samuels, 2004) \\
\hline 26 & View & (Zhu et al., 2006) \\
\hline 27 & Exterior Condition & Own research \\
\hline 28 & $\begin{array}{l}\text { Availability of Waste } \\
\text { Management }\end{array}$ & (Joseph, 2006; Mulliner \& Maliene, 2011) \\
\hline 29 & Safety Level & (Hipp, 2010; Samuels, 2004) \\
\hline 30 & Theme or Concept & Own research \\
\hline 31 & Availability of Child Care & (Mulliner \& Maliene, 2011) \\
\hline 32 & Electrical Supply & (Maliene \& Malys, 2009; Mulliner \& Maliene, 2011) \\
\hline
\end{tabular}

\section{Measuring Sustainable Housing Affordability}

The assessment of the effectiveness of sustainability application is a complex process which need in-depth analysis and through process. Pullen et al. (2010) stressed the need for a more integrated system-based approach in assessing social sustainability. Meanwhile, Mulliner and Maliene (2011) propose a set of criteria to represent sustainable housing affordability. Therefore, in order to ensure the successful of sustainability concept in housing project, there is a need to establish a systematic concept and approach in Malaysia to be as a guideline and assessment system.

Most housing economist focuses on housing price rather than holistic measures of the condition, locational attributes and neighbourhood characteristic (Bogdon \& Can, 1997). In the built environment, a Complex Proportional Assessment (COPRAS) method can be used as a tool to assess sustainable housing affordability. The method is suitable for cases where data are expressed 
PLANNING MALAYSIA

Sustainable Urban Development

in interval forms (Popović et al. (2012) and used to determine the priority and the utility degree of alternatives (Zavadskas \& Kaklauskas, 1996; Zavadskas et al., 2008). COPRAS is particularly useful in making a highly complex decision by applying weight or priorities (Aruldoss et al. (2013), involving a careful selection of resources to ensure the accuracy of criteria, alternatives or factors (Haarstrick $\&$ Lazarevska, 2009). COPRAS has gained wide acceptance throughout different sector due to its effectiveness and simple process.

\section{METHODOLOGY}

Malaysia sits within the region of South East Asia and made up of Peninsular Malaysia (West Malaysia) and East Malaysia (comprising Sabah and Sarawak). Sabah is the second largest state in Malaysia and also the second most populous state in the country. Greater Kota Kinabalu was chosen as the geographical area of this study. The area represents the most active area for housing development in East Malaysia. The contiguous built-up urban agglomeration around the city goes beyond the south side and into the district of Putatan, and to a lesser but growing extent into the district of Tuaran.

The questionnaires were distributed to residents within six of the most demanded residential areas namely Sembulan, Inanam, Bundusan, Sepanggar, Tuaran and Putatan. The purpose of the questionnaires was to verify and elicit respondents' opinion by assessing their existing housing unit in relation to the proposed criteria that constitute sustainable housing affordability. Out of 600 distributed questionnaires, 497 were answered by valid respondents of which $11 \%$ were from Sembulan, 29\% from Inanam, 21\% from Bundusan, 15\% from Sepanggar, $12 \%$ from Tuaran and 12\% from Putatan.

The questionnaires consist of 26 criteria (F1 - F26) to be chosen by respondents (Table 2). Respondents distinguish each factor based on its relative importance towards sustainable housing affordability. Responses are ranked on a five-point Likert Scale. Likert scale was used because of its simplicity in expressing the respondent level of agreement (Allen et al, 2007).

\section{Evaluation of Sustainable Housing Affordability}

The data were analysed using COPRAS method which involves five main steps which based on the model developed by Kaklauskas et al.(2005, 2007a; 2007b) and Mulliner et al.(2013).

1. The main purpose of this assessment is to measure sustainable housing affordability in the chosen areas to create a ranking of alternatives. Thus, COPRAS can handle such problem involving both positive and negative factors that influence the decision-making. The following formula is used by taking the overall mean score to allow direct comparison between all factors: 
Rosli Said, Rohayu Ab Majid, Anuar Alias, Yasmin Mohd Adnan \& Muhammad Najib Razali Sustainable Housing Affordability in Sabah

$$
m_{p q}=\frac{\overline{\mathrm{w}}_{p q}}{\sum_{q=1}^{n} x_{p q}} x_{p q}
$$

Where $\mathrm{x}_{\mathrm{pq}}$ is the value of the $p$-th criterion of the $q$-th alternative, and $\overline{\mathrm{w}}_{\mathrm{pq}}$ is the weight of the $p$-th criterion. The $q$ represents alternative residential areas.

Table 2 identifies the selected criteria of sustainable housing affordability in Malaysia and calculates overall mean score for the identified criteria. The table shows that the highest score went to the 'housing price' and followed by 'the safety level of development area' which is the second most important criterion. The least important criterion is 'near to education' where most respondents did not find it important as compared to the rest of the criteria.

Table 2: Selected Criteria and the Overall Mean Score

\begin{tabular}{|c|c|c|c|}
\hline Factors & Characteristics & $\mathbf{N}$ & $\begin{array}{l}\text { Mean Score } \\
\text { (overall) }\end{array}$ \\
\hline F1 & Housing Price & 484 & 4.3657 \\
\hline $\mathrm{F} 2$ & Housing Type & 483 & 3.7743 \\
\hline F3 & Housing Finishes & 483 & 3.7433 \\
\hline F4 & Housing Design & 483 & 3.6791 \\
\hline F5 & Position of the unit in Layout Plan & 482 & 3.4004 \\
\hline F6 & Size of Built-up Area & 481 & 3.5010 \\
\hline F7 & Size of Land Area & 481 & 3.5509 \\
\hline F8 & Age of the Unit & 480 & 3.7042 \\
\hline F9 & Topography & 482 & 3.6349 \\
\hline F10 & Property Interest & 482 & 4.0809 \\
\hline F11 & Near to Commercial Area & 484 & 3.3843 \\
\hline F12 & Near to Hospitals & 484 & 3.7169 \\
\hline F13 & Near to Post Office & 484 & 3.3202 \\
\hline F14 & Near to Recreation Area, Public Space & 484 & 3.4463 \\
\hline F15 & Near to Transportation & 484 & 3.5289 \\
\hline F16 & Near to Education & 483 & 3.1222 \\
\hline F17 & Near to Workplace & 484 & 3.7748 \\
\hline F18 & Environmental Quality & 481 & 3.9730 \\
\hline F19 & Security & 481 & 4.1289 \\
\hline $\mathrm{F} 20$ & Traffic Congestion & 482 & 3.7842 \\
\hline $\mathrm{F} 21$ & Density & 481 & 3.7318 \\
\hline F22 & View & 482 & 3.7884 \\
\hline $\mathrm{F} 23$ & Exterior Condition & 481 & 3.8274 \\
\hline F24 & Availability of Waste Management & 481 & 4.0062 \\
\hline $\mathrm{F} 25$ & Safety Level & 483 & 4.3292 \\
\hline F26 & Theme or Concept & 483 & 3.7702 \\
\hline
\end{tabular}

Table 3 derives the relative weight for each factor, $\overline{\mathrm{w}}$ and an individual mean score of each alternative area, which is essential for the next step of using the COPRAS method. 
PLANNING MALAYSIA

Sustainable Urban Development

Table 3: The weight and means score for each alternative area

\begin{tabular}{|c|c|c|c|c|c|c|c|}
\hline Factors & Weight, q & Sembulan & Inanam & Bundusan & Likas & Tuaran & Putatan \\
\hline F1 & 2.620 & 4.364 & 4.394 & 4.465 & 4.178 & 4.224 & 4.509 \\
\hline F2 & 2.265 & 3.722 & 3.542 & 3.960 & 3.973 & 3.931 & 3.655 \\
\hline F3 & 2.247 & 3.778 & 3.479 & 3.901 & 3.945 & 3.914 & 3.655 \\
\hline F4 & 2.208 & 3.685 & 3.451 & 3.911 & 3.959 & 3.690 & 3.455 \\
\hline F5 & 2.041 & 3.407 & 3.106 & 3.600 & 3.740 & 3.569 & 3.164 \\
\hline F6 & 2.101 & 3.685 & 3.191 & 3.650 & 3.726 & 3.707 & 3.327 \\
\hline F7 & 2.131 & 3.685 & 3.254 & 3.677 & 3.808 & 3.793 & 3.364 \\
\hline F8 & 2.223 & 3.796 & 3.468 & 3.920 & 3.877 & 3.810 & 3.481 \\
\hline F9 & 2.182 & 3.519 & 3.458 & 3.950 & 3.795 & 3.724 & 3.327 \\
\hline F10 & 2.449 & 4.018 & 3.965 & 4.400 & 4.083 & 4.121 & 3.818 \\
\hline F11 & 2.031 & 3.667 & 3.496 & 3.208 & 2.877 & 3.263 & 3.927 \\
\hline F12 & 2.231 & 3.719 & 3.709 & 3.673 & 3.616 & 3.737 & 3.927 \\
\hline F13 & 1.993 & 3.193 & 3.355 & 3.426 & 3.288 & 3.053 & 3.491 \\
\hline F14 & 2.068 & 3.474 & 3.418 & 3.436 & 3.534 & 3.228 & 3.618 \\
\hline F15 & 2.118 & 3.579 & 3.589 & 3.396 & 3.562 & 3.140 & 3.927 \\
\hline F16 & 1.874 & 3.281 & 2.787 & 3.480 & 3.411 & 2.930 & 2.982 \\
\hline F17 & 2.266 & 4.053 & 3.922 & 3.644 & 3.301 & 3.702 & 4.055 \\
\hline F18 & 2.385 & 3.895 & 3.872 & 4.091 & 4.096 & 4.036 & 3.873 \\
\hline F19 & 2.478 & 4.140 & 3.979 & 4.150 & 4.342 & 4.250 & 4.055 \\
\hline F20 & 2.271 & 3.719 & 3.564 & 3.822 & 4.178 & 3.839 & 3.764 \\
\hline F21 & 2.240 & 3.643 & 3.546 & 3.782 & 4.110 & 3.643 & 3.796 \\
\hline F22 & 2.274 & 3.804 & 3.674 & 3.653 & 4.164 & 3.804 & 3.800 \\
\hline F23 & 2.297 & 3.679 & 3.681 & 3.733 & 4.292 & 3.786 & 3.964 \\
\hline F24 & 2.405 & 3.965 & 3.787 & 4.010 & 4.288 & 4.091 & 4.148 \\
\hline F25 & 2.598 & 4.561 & 4.099 & 4.376 & 4.466 & 4.518 & 4.218 \\
\hline F26 & 2.263 & 3.596 & 3.631 & 3.851 & 4.329 & 3.643 & 3.545 \\
\hline
\end{tabular}

2. The weighted results are summarised to normalise the decisionmaking matrix by calculating the sums of both positive and negative alternatives (Table 4). The sums of $S_{+q}$ of attributes values which provide larger values are preferable (the direction of optimization and maximisation) as compared to other alternatives. The sums of $\mathrm{S}_{-\mathrm{q}}$ of attributes values which constitute smaller values are preferable (the direction of optimization and minimisation) as compared to other alternatives. The significance (priority) of the comparative alternative is determined on the basis of a greater/lesser criterion values that satisfies sustainable housing affordability. The formula to calculate the sums are as follows:

$$
\begin{aligned}
& S_{q}^{+}=\sum_{e_{p}=+} m_{p q} \\
& S_{q}^{-}=\sum_{e_{p}=-} m_{p q}
\end{aligned}
$$


Rosli Said, Rohayu Ab Majid, Anuar Alias, Yasmin Mohd Adnan \& Muhammad Najib Razali Sustainable Housing Affordability in Sabah

Table 4: Normalized decision matrix by alternative area

\begin{tabular}{llcccccc}
\hline Factors & Z & Sembulan & Inanam & Bundusan & Sepanggar & Tuaran & Putatan \\
\hline F1 & - & 0.438 & 0.441 & 0.448 & 0.419 & 0.424 & 0.452 \\
F2 & + & 0.370 & 0.352 & 0.394 & 0.395 & 0.391 & 0.363 \\
F3 & + & 0.374 & 0.345 & 0.387 & 0.391 & 0.388 & 0.362 \\
F4 & + & 0.367 & 0.344 & 0.390 & 0.395 & 0.368 & 0.344 \\
F5 & + & 0.338 & 0.308 & 0.357 & 0.371 & 0.354 & 0.314 \\
F6 & + & 0.364 & 0.315 & 0.360 & 0.368 & 0.366 & 0.328 \\
F7 & + & 0.364 & 0.321 & 0.363 & 0.376 & 0.375 & 0.332 \\
F8 & - & 0.378 & 0.345 & 0.390 & 0.386 & 0.379 & 0.346 \\
F9 & - & 0.353 & 0.346 & 0.396 & 0.380 & 0.373 & 0.333 \\
F10 & + & 0.403 & 0.398 & 0.442 & 0.410 & 0.414 & 0.383 \\
F11 & + & 0.364 & 0.348 & 0.319 & 0.286 & 0.324 & 0.390 \\
F12 & + & 0.371 & 0.370 & 0.366 & 0.360 & 0.372 & 0.391 \\
F13 & + & 0.321 & 0.338 & 0.345 & 0.331 & 0.307 & 0.351 \\
F14 & + & 0.347 & 0.341 & 0.343 & 0.353 & 0.322 & 0.361 \\
F15 & + & 0.358 & 0.359 & 0.339 & 0.356 & 0.314 & 0.393 \\
F16 & + & 0.326 & 0.277 & 0.346 & 0.339 & 0.291 & 0.296 \\
F17 & + & 0.405 & 0.392 & 0.364 & 0.330 & 0.370 & 0.405 \\
F18 & + & 0.389 & 0.387 & 0.409 & 0.409 & 0.403 & 0.387 \\
F19 & + & 0.412 & 0.396 & 0.413 & 0.432 & 0.423 & 0.403 \\
F20 & - & 0.369 & 0.354 & 0.379 & 0.415 & 0.381 & 0.374 \\
F21 & - & 0.362 & 0.353 & 0.376 & 0.409 & 0.362 & 0.378 \\
F22 & + & 0.378 & 0.365 & 0.363 & 0.414 & 0.378 & 0.377 \\
F23 & + & 0.365 & 0.366 & 0.371 & 0.426 & 0.376 & 0.394 \\
F24 & - & 0.393 & 0.375 & 0.397 & 0.424 & 0.405 & 0.411 \\
F25 & + & 0.452 & 0.406 & 0.433 & 0.442 & 0.447 & 0.418 \\
F26 & + & 0.360 & 0.364 & 0.386 & 0.434 & 0.365 & 0.355 \\
\hline
\end{tabular}

3. The relative significance $H_{q}$ of each alternative, based on positive (+) and negative (-), are calculated using the formula below:

$$
H_{q}=S_{q}^{+}+\frac{S_{\min }^{-} \sum_{q=1}^{n} S_{q}^{-}}{S_{q}^{-} \sum_{q=1}^{n} \frac{S_{\min }^{-}}{S_{q}^{-}}}=S_{q}^{+}+\frac{\sum_{q=1}^{n} S_{q}^{-}}{S_{q}^{-} \sum_{q=1}^{n} \frac{1}{S_{q}^{-}}}
$$

Where the minimum values $\mathrm{S}_{\mathrm{q}}^{-}$are cancelled, the higher value corresponds to a more sustainable housing affordability.

4. At this stage, prioritisation is determined by the largest $H_{q} . H_{\max }$ is the optimal value and the best among alternatives. Alternatives are ranked from highest to lowest of relative significance $H_{q}$.

5. The degree of utility is determined by comparing each alternative by the one alternative with $H_{\max }$. The area with the highest degree of utility $\left(\check{\mathrm{u}}_{\mathrm{q}}=\right.$ $100 \%$ ) represents an area that most satisfies sustainable housing affordability. Other alternatives will show utility values ranging from $0 \%-100 \%$ indicators of 
the worst to the best-case scenario. The degree of utility $\check{\mathrm{u}}_{\mathrm{q}}$ of the alternatives $O_{q}$ is calculated by the following formula:

$$
\check{\mathrm{u}}_{u}=\frac{H_{q}}{H_{\max }} 100 \%
$$

\section{RESULTS \& DISCUSSION}

The step-by-step procedure in COPRAS assessment produces the final results (Table 5). Table 5 shows that the location that best describes the most sustainable housing affordability is Sembulan as reflected in utility degree of $100 \%$. The second best area is Likas with utility degree of $97.81 \%$. The next suitable area is Bundusan with utility degree of $96.66 \%$, followed by Inanam at $96.60 \%$. Tuaran has shown the lowest ranking as reflected in utility degree of $96.51 \%$ that is slightly lower than Putatan with utility degree of $96.51 \%$.

The results also show that most of the population in Kota Kinabalu concerned with house price as compared to other factors. Surprisingly, the respondents are willing to discount all these factors in favour of housing quality and the environment. Sembulan did score very high in some factors such as high accessibility and low density. The results also indicate that this area is the best performing area in relation to the predetermined factors of sustainable housing affordability. Sembulan scored relatively low in building-related factors such as housing type, finishes, design, interior features and position of the house in layout plan.

Each of the six areas above had almost equal measures of utility shows that the difference between the best alternative (Sembulan) to the worst alternative (Tuaran) is minuscule at $4.5 \%$. This could be translated in layman's terms as the advantages and disadvantages of both areas are almost equal and often interchangeable with one another. In other words, Sembulan proved to be sustainable in terms of housing affordability, and it is the best area to stay as compared to the rest of the alternatives. However, great improvement can be done in the analysis by focusing on a smaller area, i.e. by zoning, precinct or section within the larger area. The key finding shows that the identification of appropriate area would assist in ensuring high quality of life for future affordable housing development. Therefore, COPRAS method has substantially demonstrated its effectiveness in assessing the sustainability of different areas by providing the utility degree of alternatives. Its flexibility could be applied to any region and place, and the weight can be adjusted to suit any context. 
Rosli Said, Rohayu Ab Majid, Anuar Alias, Yasmin Mohd Adnan \& Muhammad Najib Razali Sustainable Housing Affordability in Sabah

Table 5: Final results of sustainable housing affordability

\begin{tabular}{ccccccc}
\hline & Sembulan & Inanam & Bundusan & Likas & Tuaran & Putatan \\
\hline S+ & 8.650 & 8.080 & 8.893 & 9.039 & 8.666 & 8.183 \\
S- & 7.667 & 7.679 & 8.480 & 8.424 & 8.451 & 7.788 \\
H & 17.150 & 16.567 & 16.578 & 16.775 & 16.378 & 16.551 \\
Priority & 1 & 4 & 3 & 2 & 6 & 5 \\
ǔ(\%) & $100.00 \%$ & $96.60 \%$ & $96.66 \%$ & $97.81 \%$ & $95.50 \%$ & $96.51 \%$ \\
\hline
\end{tabular}

\section{CONCLUSION}

Overall, the rising of house price and cost of living compel the purchasers to find the best area to allocate themselves in any city. Over time, nothing else can be based upon in their decision-making process other than price and household income. The marketplace has to be reassessed in a more discriminating way in order to find an alternative to what could be the most important to individual and/or society. This paper has adequately demonstrated the necessity to shift our emphasis from the traditional price-income-cost genre towards sustainabilityquality-affordability value. Housing affordability is one of the main concerns for any government. As such, the market players also play a major role in order to make a distinction between cheap housing and sustainable housing affordability as this issue will get even more complicated as we explore deeper into the topic. There is a necessity to have cooperation between the market players to arrive at the conclusion that what makes a house sustainable outside the limitation of simply housing cost. The government through its local authorities could adopt the same methodology for a proper planning of urban dwellings. Property developers may utilise the results to find the best area to improve their future housing development. This would prove beneficial to gain the upper hand against competing rivals. The results and method presented could also be used by the public in determining and deciding the best area to buy future housing units in fulfilling their preferences.

\section{ACKNOWLEDGEMENTS}

The authors would like to acknowledge with gratitude the funding received from the University of Malaya Research Grant (UMRG) for this research (Project No. RP007E-13SUS).

\section{REFERENCES}

Abidin, Z. N. (2010). Investigating the awareness and application of sustainable construction concept by Malaysian developers. Habitat International, 34, 421-426.

Allen, I. E. \& Seaman, C. (2007). Likert Scales and Data Analyses. Quality Progress, 40(7), 64-65.

Aruldoss, M., Lakshmi, T. M. \& Venkatesan, V. P. (2013). A survey on multi criteria decision making methods and its applications. American Journal of Information Systems, 1(1), 31-43. 
PLANNING MALAYSIA

Sustainable Urban Development

Australian Conservation Foundation (2008). Housing Affordability: More than Just Mortgage and Rent. Australian Conservation Foundation and the Victorian Council of Social Service.

Bogdon, A. S. \& Can, A. (1997). Indicators of local housing affordability: comparative and spatial approaches. Real Estate Economics, 25(1), 43-80.

Brownstone, D. \& Golob, T. F. (2009). The impact of residential density on vehicle usage and energy consumption. Journal of urban Economics, 65, 91-98.

Brundtland, G. H. (1996). Our common future revisited. Brown Journal of World Affairs, III(2), 175.

Burke, T., Pinnegar, S., Phibbs, P., Neske, C., Gabriel, M. \& Ralston, L. (2007). Experiencing the Housing Affordability Problem: Blocked Aspirations, Trade-Offs and Financial Hardships. Australian Housing and Urban Research Institute.

Clark, W., Deurloo, M. \& Dieleman, F. (2006). Residential mobility and neighbourhood outcomes. Housing Studies, 21, 323-342.

Cowan, R. \& Hill, D. (2005). Start with the Park: Creating Sustainable Urban Green Spaces in Areas of Housing Growth and Renewal. London: Commission for Architecture $\&$ the Built Environment (CABE).

Department of the Environment Heritage and Local Government Ireland (2007). Quality Housing for Sustainable Communities.

Drexhage, J. \& Murphy, D. (2010). Sustainable Development: From Brundtland to Rio 2012. Background Paper for High Level Panel on Global Sustainability Meeting, September 2010, New York.

Fierro, K., Fullerton, T. \& Donuan-Callejo, K. (2009). Housing attribute preference in a northern Mexico metropolitan economy. Atlantic Economic Journal, 37, 159-172.

Haarstrick, A. \& Lazarevska, A. (2009). Multi criteria decision making (mcdm)- a conceptual approach to optimal landfill monitoring. Paper presented at the 3rd International Workshop "Hydro-Pysico-Mechanics of Landfills", Braunschweig, Germany.

Hipp, J. (2010). What is the 'neighbourhood' in neighbourhood satisfaction? Comparing the effects of structural characteristics measured at the micro neighbourhood and trace levels. Urban Studies, 47, 2517-2536.

Hurtubia, R., Gallay, O. \& Bierlaire, M. (2010). Attributes of households, locations and real estate markets for land use modelling. Sustain City Working Paper, 2.7, EPFL, Lausanne.

Isalou, A. A., Litman, T. \& Shahmoradi, B. (2014). Testing the housing and transportation affordability index in a developing world context: a sustainability comparison of central and suburban districts in Qom, Iran. Transport policy, 33, 33-39.

Joseph, K. (2006). Stakeholder participation for sustainable waste management. Habitat International, 30, 863-871.

Kaklauskas, A., Zavadskas, E. K., Banaitis, A. \& Satkauskas, G. (2007a). Defining the utility and market value of a real estate: a multiple criteria approach. International Journal of Strategic Property Management, 11(2), 107-120.

Kaklauskas, A., Zavadskas, E. K. \& Raslanas, S. (2005). Multivariant design and multiple criteria analysis of building refurbishments. Energy and Buildings, 37, 361-372.

Kaklauskas, A., Zavadskasb, E. K. \& Trinkunasa, V. (2007b). A multiple criteria decision support on-line system for construction. Engineering Applications of Artificial Intelligence, 20(2), 163-175.

Kates, R. W., Parris, T. M. \& Leiserowitz, A. A. (2005). What is Sustainable Development? Goals, Indicators, Values and Practice. Environment: Science and Policy for Sustainable Development, 47, 8-21. 
Rosli Said, Rohayu Ab Majid, Anuar Alias, Yasmin Mohd Adnan \& Muhammad Najib Razali

Sustainable Housing Affordability in Sabah

King, L. A. (2008). Sustainable Community Development Code: Housing Affordability. Arlington, Virginia: Housing Food System.

Lu, M. (2002). Are pastures greener? Residential consequence of migration. International Journal of Population Geography, 8, 201-216.

Maliene, V. \& Malys, N. (2009). High quality housing- a key issue in delivering sutainable communities. Journal of Building and environment, 44, 426-430.

Mcalpine, P. \& Birnie, A. (2007). Is there a correct way of establishing sustainability indicators? The case of sustainability indicator development on the Island of Guernsey. Local Environment: The International Journal of Justice and Sustainability, 10(3), 243-257.

Medineckiene M., Turskis Z. \& Zavadskas E.K. (2010). Sustainable construction taking into account the building impact on the environment. Journal of Enviromental Engineering and Landsape Management, 18(2), 118-127.

Morgan, J., \& Talbot, R. (2001). Sustainable social housing for no extra cost? In E. Burton, M. Jenks \& K. Williams (Eds.) Achieving sustainable urban form. New York: Routledge.

Mulliner, E. \& Maliene, V. (2011). Criteria for sustainable housing affordability. Journal of Environmental Engineering, 3, 966-973.

Mulliner, E., Smallbone, K. \& Maliene, V. (2013). An assessment of sustainable housing affordability using a multiple criteria decision making method. Omega-International Journal of Management Science, 41(2), 270-279. doi: 10.1016/j.omega.2012.05.002

Popović, G., Stanujkić, D., \& Stojanović, S. (2012). Investment projects selection by applying copras method and imprecise data. Serbian Journal of Management, 7(2), 2570269.

Pullen, S., Arman, M., Zillante, G., Zuo, J., Chileshe, N. \& Wilson, L. (2010). Developing an assessment framework for affordable and sustainable housing. Australasian Journal of Construction Economics and Building, 10(1/2), 48-64.

Samuels, I. (2004). What home buyers want: attitudes and decision-making among home buyers. London: Commission for Architecture \& the Built Environment.

Shen, L.-Y., Ochoa, J. J., Shah, M. N. \& Zhang, X. (2011). The application of urban sustainability indicators: a comparison between various practices. Habitat International, 35, 17-29.

The Ministry of Urban Wellbeing Housing and Local Government Malaysia (2013). The National Housing Policy Housing The Nation: Policies Issues and Prospects. Kuala Lumpur: Cagamas Holdings.

Turcu, C. (2012). Local experiences of urban sustainability: Researching housing market renewal interventions in three english neighbourhoods. Progress in Planning, 78, 101-150.

Zavadskas, E. K. \& Kaklauskas, A. (1996). Multiple criteria evaluation of buildings. Vilnius, Lithuania.

Zavadskas, E. K., Kaklauskas, A., Turskis, Z. \& Tamosaintinei, J. (2008). Multi-attribute decision-making model by applying grey numbers. Institute of Mathematics and Informatics, 20(2), 305-320.

Zhu, X., Liu, S. \& Yeow, M.-C. (2006). Accessibility analysis for housing development in Singapore with GIS and multi-criteria analysis methods. Applied GIS, 2(2), 13.1113.12 . 